\title{
AMENDMENTS AND UPDATES TOE THE BUDGET PROCESS REGULATORY FRAMEWORK
}

\author{
M.Goldin
}

Some amendments were made to a series of federal laws in August 2013, in particular to the Budget Code of the Russian Federation and the Administrative Offences Code of the Russian Federation. These amendments are to significantly alter the framework of public (municipal) control in the area of fiscal relations.

Federal Law dd. 23.07.2013, No. 252-FZ "On the introduction of amendments to the Budget Code of the Russian Federation and Certain Legal Acts of the Russian Federation" (hereinafter referred to as "the Law No. 252-FZ) took effect on August 4, 2013. The law introduced amendments concerning public (municipal) financial control in the field of budgetary relations to a series of federal laws, including the Budget Code of the Russian Federation (hereinafter referred to as "the BC of Russia") and the Administrative Offences Code of the Russian Federation (hereinafter referred to as "the AOC of Russia").

The law defines public (municipal) control in the field of budgetary relations as public (municipal) financial control which is exerted for the purpose of ensuring compliance with the fiscal legislation of the Russian Federation and other laws and regulations which regulate budgetary legal relations.

Legal regulation in the field of public (municipal) financial control is focused on supervising over those who involved in the budgetary process, above all, public authorities and government agencies.

Public (municipal) financial control can be divided into external and internal, preliminary, and follow-up types of public (municipal) financial control.

External public (municipal) financial control refers to supervisory activity performed respectively by the Accounts Chamber of the Russian Federation, auditing $\&$ accounting bodies of the constituent territories of the Russian Federation, and municipalities.

Internal public (municipal) financial control refers to supervisory activity performed by the Federal Service for Financial and Budget Supervision, public (municipal) financial control bodies of constituent territories of the Russian Federation, local administrative bodies, the Federal Treasury (finance bodies of constituent territories of the Russian Federation or municipalities).

Preliminary control and follow-up are distinguished by their place in the budgetary process rather than controlled entities. Preliminary control is generally performed prior to an y financial operation with a view to preventing or restraining budgetary violations in the course of implementation of budget of the Rus- sian budget system. Follow-up control is generally performed in arrears on the basis of the results of implementation of budgets of the Russian budget system with a view to checking legality of their implementation, and reliability of accounting and reporting.

Following are the methods (procedures) of public (municipal) financial control that are defined in the BC of Russia, as amended by the Law No. 252-FZ:

1) inspection refers to performance of control actions with regard to the activity of an entity during a certain period, including documentary and actual examination of financial and economic operations for legality, budget accounting and budget reporting for reliability. Inspections can be divided into cameral and field (on-site) ones;

2) audit refers to a comprehensive inspection of operations and activities of an entity, including performance of control actions such as documentary and actual examination of the entirety of performed financial and economic operations for legality and correct recognition thereof in the entity's accounting book and budgetary reporting;

3) survey refers to analysis and assessment of the status of a certain type of activity of an entity, including internal financial control and internal financial statement audit which may be performed by chief budget controllers, chief budget revenue controllers, chief budget deficit sources of financing controllers;

4) authorization to operate refers to an endorsement which is made after the examination of documents submitted for the purpose of financial operations. The endorsement confirms that the aforementioned documents contain information and/or this information meets the requirements set forth in the budget legislation of the Russian Federation and other laws and regulations which regulate budgetary legal relations.

Results of inspections and audits are documented in the form of inspection or audit certificate, whereas results of surveys are documented as final report.

Grounds and procedure for inspections, audits, and surveys, including a list of government officials authorized to make decisions on initiation thereof and other 
procedural issues, are set forth in a regulation which establishes the legal status of a respective public (municipal) financial control body.

As a general rule, once an inspection (audit) has revealed budgetary violations, the officer of the public (municipal) financial control body will be entitled to forward a representation and/or ordinance to the entity which has been subject to control actions, and a notice of fiscal measures of enforcement to the financial body which is authorized to take decisions on fiscal measures of enforcement.

The foregoing amendments make significant changes in the legal regulation of liability for violations of the budget legislation of the Russian Federation. Previously, violation of the budget legislation was defined as violation of nothing but the provisions set forth in the $B C$ of Russia. However, the provisions of the budget legislation of the Russian Federation are also available in other laws and regulations which make up the budgetary law framework, and the foregoing provisions may be breached not only by those involved in the budgetary process, but also other persons, which, in its turn, entails taking not only budgetary and legal but also other penalties.

Therefore, a new term (budgetary violation) has been introduced into the $\mathrm{BC}$ of Russia, which is defined as violation of all legal acts regulating budgetary legal relations, and contracts (agreements) under which budgetary funds are allocated, action (omission) of finance bodies, chief budget controllers. Furthermore, liability of those not involved in the budgetary process is regulated by other branches of law.

In addition, the BC of Russia establishes classification of fiscal measures of enforcement in case of budget violations:

- indisputable recovery of the amount of funds allocated from a budget of the Russian budget system to other budget of the Russian budget system ;

- indisputable recovery of the amount payable for the use of funds allocated from a budget of the Russian budget system to other budget of the Russian budget system ;

- indisputable collection of fines payable for overdue repayment of budgetary funds ;

- suspending (reducing) the provision of interbudget transfers (save for subventions) ;

- delegating a part of the powers of the chief budget controller, controller and recipient of budgetary funds to a respective budget controller.

Amendments to the AOC of Russia contain some new provisions in addition to the restated provisions such as "unintended use of budgetary funds" (Article 15.14. of the AOC of Russia) and "failure to repay or default in repayment of the state budget loan" (Article 15.15. of the AOC of Russia):

- failure to pay or default in payment for the use of the state budget loan (Article 15.15.1. of the AOC of Russia);

- violation of the terms of the state budget loan (Article 15.15.2. of the AOC of Russia);

- violation of the terms of inter-budget transfers (Article 15.15.3. of the AOC of Russia);

- violation of the terms of budget investments (Article 15.15.4. of the AOC of Russia);

- violation of the terms of subsidies (Article 15.15.5. of the AOC of Russia);

- violation of the procedure for submission of budgetary reporting (Article 15.15.6. of the AOC of Russia);

- violation of the procedure for compiling, approval, and maintaining of budget estimates (Article 15.15.7. of the AOC of Russia);

- violation of the ban on budget loans and/or subsidies (Article 15.15.8. of the AOC of Russia), and some more provisions. 